\title{
Cenas de um encontro desencontrado
}

Transcorria o ano de 2006, no seu dorso cavalgava o malfadado Acordo Bilateral de Regularização Migratória Brasil/Bolívia. Antes mesmo da aurora despontar (se é que é possível falar dela desde um lugar que nunca escurece), na região central da metrópole paulista, o endereço da rua Glicério 225 viase tomado, diariamente, por bolivianos que afluíam dos mais diversos pontos da megalópole. Tão logo os portões abriam alas, adentravam o largo pátio da Missão Scalabriniana Nossa Senhora da Paz e, ao fundo, dirigiam-se ao Centro Pastoral dos Migrantes.

lam ao encontro do reconhecimento legal de sua legítima presença no país. Mas para muitos, assim que chegava sua vez de sentar numa das cadeiras em frente aos que ali estavam em mutirão para auxiliá-los, principiava o desencontro. Diga-se, as pessoas atendentes eram treinadas para a escuta e conhecedoras do distanciamento, não geográfico, mas derivado das lógicas que regem cotidianos tão díspares: de um lado, uma sociedade marcada pelo circuito frenético da mercadoria e, como se não bastasse, encouraçada numa grossa e pesada burocracia; do outro, a lógica dos que na Bolívia deixaram o altiplano, onde uma cultura milenar finca raízes e muitos, pela primeira vez, literalmente trombavam com a modernidade e nela viam-se enredados em suas contradições. Por isso, toda paciência, todo vagar na hora da explicação do quê fazer, nunca era demais. Além da fala, os acompanharia um papel com todos os passos a serem dados no trâmite do penoso processo da regularização.

Porém, ao término de cuidadosa e repetida explicação, e da entrega do papel, no momento em que tudo estava aparentemente aclarado, só faltando o aperto de mão desejando boa sorte e a oferta do retorno caso necessidade houvesse, do lado de quem deveria ceder espaço para o seguinte da fila, recorrentemente, em voz branda e com semblante de total estranhamento, ouvia-se: "Una preguntita más: lo que es mismo que debo hacer"?

Xerox, fotocópia, autenticação, reconhecimento de firma, processo, 
cartório, vias e guias, DARFS... Fico eu, filho de camponeses, imaginando meus pais, semialfabetizados, falantes do dialeto vêneto, naquelas cadeiras, portando em suas mãos uma pasta repleta de papéis... Se viver é perigoso, como diria Guimarães Rosa pela boca de Riobaldo, migrar é desafiador e, por vezes, constrangedor.

Um belo dia, na meia-tarde, deixo eu minha escrivaninha e dirijo-me ao corredor da ala externa que oferece, do alto do primeiro andar, uma visão panorâmica do asfalto duro e escuro que reveste o pátio da Missão Scalabriniana, cuja centralidade é ocupada pela Igreja Nossa Senhora da Paz, construída pela coletividade italiana no início dos anos 1940, mas que tempo mais tarde acostumou-se a recepcionar os mais variados rostos - coreanos, vietnamitas, chilenos, uruguaios, bolivianos, paraguaios, peruanos, colombianos e, aninhando a todos num só balaio, os africanos, além dos mais recentes, os haitianos, sem falar dos nordestinos, presentes desde o nascedouro.

Enquanto eu lá de cima dava, infelizmente, umas tragadas no pito, presenciei a cena cabal do desencontro entre as duas lógicas referidas.

Uma família boliviana deixa as dependências do Centro Pastoral dos Migrantes. Ao invés do habitual caminho em direção à rua, dirige-se aos pés da parede da Igreja. Lá o sol cedia espaço para uma franja marcada pela sombra, um refúgio momentâneo, pois do alto os raios do astro maior afugentavam qualquer vivente naquela tarde. Apenas algumas nuvens imbríferas principiavam a toldar o pouco azul que o céu da metrópole exibia. Como a casar com o contexto, um vento ensaiava o que horas depois aconteceria.

A família era composta pelo casal, um garoto com idade aproximada de seis anos e um irmãozinho que já aprendera a dar os primeiros passos. Primeiros passos, imagino eu, ensaiados em reduzido espaço, quiçá em meio a quantos retalhos! Aquele pequeno sorvia o vento como o leite materno e, de braços abertos, cambaleando equilibradamente, danou-se a correr pela imensidão representada por aquele chão recoberto de betume. Mas o voo da liberdade não tardou a ser tolhido. A lógica do encontro com a legalização migratória falou mais alto. Ele foi tomado pela mão da mãe que o aconchegou, ou arrastou? Digamos, reuniu junto ao irmãozinho maior e ao pai, onde este já havia colocado ao chão a pasta com os documentos. Prostrado, o genitor já iniciara a perfilar os brancos papéis sobre o negro asfalto e os dispunha, cuidadosamente, um a um, mas não sem relutâncias. A mãe depressa ajoelhou também para auxiliar na tarefa, ao que o filhote maior se somou. $O$ vento o exigia. Além das mãos, os joelhos eram utilizados para impedir o voo dos papéis, quando não os cotovelos.

Mas o descuidado de quem inventou os papéis imperiosamente necessários para o processo de regularização, os inventou flexíveis, flácidos, maleáveis e, sobretudo, leves, verdadeiro empecilho para o momento da arrumação. Não havia sobras de mãos para identificá-los, separá-los, ajeitá-los. Quando a mão direita do pai aventurava-se a esta tarefa maior, duas ou três folhas aderiam 
às asas do vento, sem contar que a mãe, no afã de colaborar, possibilitara o desvencilhamento do pequenino e, ao dar-se conta, o avistou distante competindo com os papéis voadores.

Mas o pátio não era só deles, havia transeuntes e alguns carros adentravam. Lembro, no meu peito o coração doeu. Eles se foram com os papéis arrumados do jeito que deu - desencontrados! $\mathrm{E}$ eu, deixando a sacada, tive a mente assim invadida: Que sina! Tornou-se inimigo, naquele instante, quem melhor os compreendeu - o vento!

Hoje, distante das lufadas que dificilmente esquecerei, torço para que os nomes daquele casal - para quem o acordo bilateral só surtiu efeito provisório não integrem o percentual dos que tiveram seus processos indeferidos na Anistia que se seguiu em 2009, pois imagino, sem ter presenciado, outros tantos ventos que tiveram que enfrentar.

Dirceu Cutti

São Paulo, março de 2012 
